\title{
PENGARUH METODE PROSES SINTESIS ANALOG KURKUMIN ASIMETRIS TERHADAP EFEK HEPATOPROTEKTIF MENCIT (Mus musculus L.)
}

\section{Effect of Synthesis Process Method of Asymmetric Curcumin Analog on the Hepatoprotective Effect of Mice (Mus musculus L.)}

\author{
Imanuel Berly Delvis Kapelle*1, Wasmen Manalu² \\ ${ }^{1}$ Jurusan Kimia, Fakultas MIPA, Universitas Pattimura, Jl. Ir. Putuhena, Kampus Poka-Ambon 97233 \\ ${ }^{2}$ Departemen Anatomi, Fisiologi dan Farmakologi, Fakultas Kedokteran Hewan, IPB, Jl. Agatis, Kampus \\ IPB Dramaga, Bogor 16680 \\ *Email: berly_mollucas@yahoo.com
}

\begin{abstract}
Asymmetric curcumin analogs (ACA) can be synthesized from cullilawan oil. ACA products can be synthesized using conventional methods and microwaves. Synthesis methods can affect physical properties and pharmacological effects. The purpose of this study was to determine the effect of the process method on the hepatoprotective ability of ACA and to determine the effective dose. ACA products were tested in vivo in mice (Mus musculus $L$.) with $\mathrm{CCl}_{4}$-induced liver damage. The parameters observed were biochemical liver enzymes (AST and $A L T)$ and histological analysis. The results showed that animals treated with ACA-k products had better weight gain, lower AST and ALT levels, and fewer histological signs of liver damage at higher ACA doses than those observed in animals that were untreated or treated with ACA-m products. Thus, asymmetric curcumin analog products that were processed by conventional method were more hepatoprotective.
\end{abstract}

Keywords: ACA, culilawan oil, hepatoprotection, in vivo, product diversification

\begin{abstract}
ABSTRAK
Analog kurkumin asimetris (AKAS) dapat disintesis dari minyak kulit lawang. Produk AKAS dapat disintesis menggunakan metode konvensional dan microwave. Metode sintesis dapat mempengaruhi sifat fisik dan efek farmakologis. Tujuan dari penelitian ini adalah untuk mengetahui pengaruh metode proses pada kemampuan hepatoprotektif AKAS dan untuk menentukan dosis efektif. Produk AKAS diuji in vivo pada mencit (Mus musculus L.) dengan kerusakan hati yang diinduksi $\mathrm{CCl}_{4}$. Parameter yang diamati adalah biokimia enzim hati (AST dan ALT) dan analisis histologis. Hasil penelitian menunjukkan bahwa hewan yang diobati dengan produk AKAS-k memiliki kenaikan berat badan yang lebih baik, tingkat AST dan ALT yang lebih rendah, dan lebih sedikit tanda histologis kerusakan hati pada dosis AKAS yang lebih tinggi daripada yang terlihat pada hewan yang tidak diperlakukan atau diobati dengan produk AKAS-m. Dengan demikian, produk analog kurkumin asimetris yang diproses dengan metode konvensional lebih hepatoprotektif.
\end{abstract}

Kata Kunci: AKAS, diversifikasi produk, hepatoprotektor, in vivo, minyak lawang 


\section{PENDAHULUAN}

Minyak kulit lawang adalah minyak atsiri yang berasal dari proses penyulingan kulit kayu tanaman lawang (Cinnamomum culilawan Blume) (Gambar 1), dan mengandung senyawa safrol yang memiliki cincin dioxolane yang sangat aktif serta dapat digunakan sebagai prekursor analog kurkumin (Kapelle et al. 2016). Safrol pada suhu kamar merupakan minyak yang tidak berwarna, tetapi dapat berubah menjadi kuning jika terkena sinar matahari. Pada temperatur rendah safrol merupakan kristal berwarna putih, mempunyai bau sasafras dan rasa pedas (Villegas et al. 2011).

Bahan alam yang memiliki cincin dioxolane yang sama dengan safrol serta memiliki aktivitas sebagai anti kanker adalah piperin. Piperin merupakan senyawa alkaloid yang telah diuji aktivitasnya sebagai antioksidan dan hepatoprotektif (Mehta et al. 2012) serta dapat meningkatkan bioavailabilitas (Jin et al. 2013). Aktivitas farmakologi senyawa piperin disebabkan karena adanya cincin dioxolane, sehingga senyawa safrol dapat dikonversi menjadi produk turunan analog kurkumin.

Senyawa yang berasal dari safrol yang dapat disintesis adalah analog kurkumin simetris dan analog kurkumin asimetris (Kapelle et al. 2015a, 2015b). Produk analog kurkumin simetris (AKS; 1,5-bisbenzo[1,3]dioxol-5-yl-penta-1,4-dien-3-one) dan analog kurkumin asimetris (AKAS; 5benzo[1,3]dioxol-5-yl-1-phenyl-penta-2,4dien-1-one) memiliki perbedaan struktur pada gugus yang mengikat karbonil. Produk AKS memiliki gugus yang sama sehingga simetris, sedangkan AKAS memiliki gugus yang berbeda (asimetris).

Senyawa analog (homolog) kurkumin merupakan senyawa yang memiliki kemungkinan sifat farmakologis yang sama atau bahkan lebih baik bila dibandingkan dengan senyawa kurkumin (Thomas et al. 2010, Yang et al. 2013). Senyawa kurkumin merupakan serbuk berwarna kuning dari tanaman curcuma longa (Linn) (Dandawate et al. 2012) yang memiliki aktivitas sebagai anti kanker (Aggarwal et al. 2010, Irving et al. 2011, Ye et al. 2012, Moorthi dan Kathiresan 2013, Qian et al. 2015).

$$
\text { Kurkumin sebagai senyawa }
$$
kemopreventif yang bertujuan untuk memperlambat, memblokade atau mengembalikan proses karsinogenesis (Johnson dan Mukhtar 2007). Kurkumin dan analog kurkumin mempunyai aktivitas biologis sebagai antiinflamasi, antioksidan, antitumor, dan antikanker pencernaan, payudara, ovarium, paru-paru, maupun saraf (Shang et al. 2010). Pengaruh aktivitas tersebut dipengaruhi oleh subtituen dan struktur senyawa analog kurkumin (Anand et al. 2008). Senyawa analog kurkumin (AKS dan AKAS) telah diuji untuk aktivitas sitotoksik sel kanker payudara dan metode proses sintesis mempengaruhi aktivitasnya (Kapelle et al. 2015c). Aktivitas sebagai obat dipengaruhi oleh gugus fungsinya yang bertindak sebagai antioksidan. Aktivitas antikanker payudara untuk senyawa analog kurkumin yang memberikan sisi aktif adalah

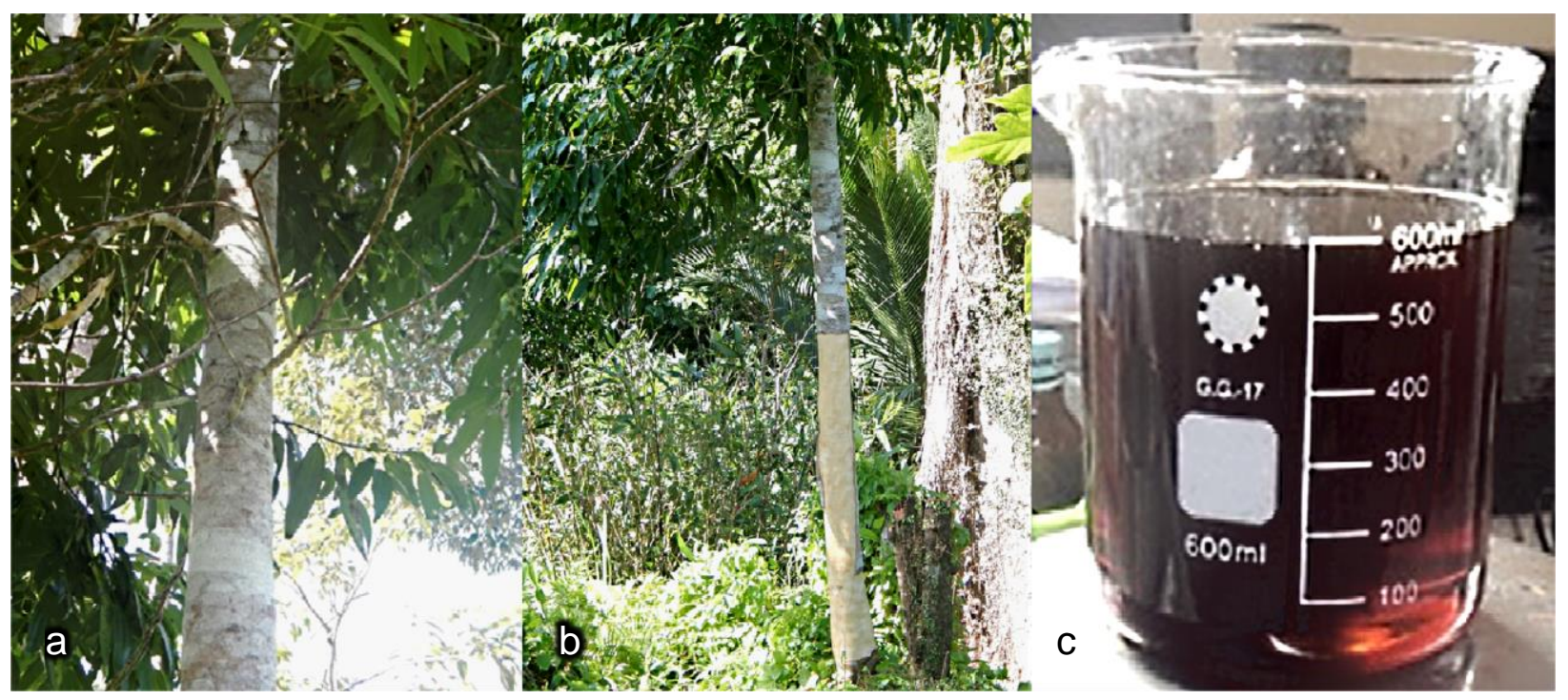

Gambar 1. a) Tanaman Lawang, b) Tanaman yang telah dipanen kulitnya, c) Minyak atsiri kulit lawang 
atom karbon pada gugus fenol (Zhang et al. 2011). Berdasarkan data hubungan struktur aktivitas menunjukkan bahwa subtituen yang memiliki sifat penarik elektron pada cincin benzena (subtituen $F$ dan epoksida) mempengaruhi sifat anti-inflamasi (Zhao et al. 2010).

Produk analog kurkumin simetris (AKS) dari minyak lawang telah diuji pengaruh hepatoprotektor pada hewan model yang diinduksi carbon tetrachloride $\left(\mathrm{CCl}_{4}\right)$ dengan membandingkan dua metode proses dan hasilnya menunjukkan bahwa produk yang diproses dengan metode konvensional lebih hepatoprotektif daripada produk yang diproses dengan metode microwave (Kapelle et al. 2019). Hati adalah organ yang sangat rentan terhadap pengaruh senyawa kimia dan sering rusak karena masuknya zat beracun. Pasokan darah ke hati berasal dari saluran pencernaan, sehingga zat beracun yang diserap oleh usus akan dibawa ke hati melalui vena portal. Zat beracun yang masuk ke hati dapat menyebabkan berbagai efek seperti steatosis, nekrosis, kolestasis, sirosis dan nilai biokimia darah (AST dan ALT) akan mengalami kenaikan. $\mathrm{CCl}_{4}$ adalah hepatotoksin yang menyebabkan kerusakan hati (Khan et al. 2012). Tujuan dari penelitian ini adalah untuk mengetahui pengaruh metode proses pada kemampuan hepatoprotektif analog kurkumin asimetris (AKAS) dari minyak lawang pada mencit jantan (Mus musculus L.) yang diinduksi oleh $\mathrm{CCl}_{4}$ dan untuk menentukan dosis efektif.

\section{BAHAN DAN METODE}

\section{Tempat dan waktu penelitian}

Penelitian ini dilakukan di Laboratorium Kimia Organik dan Laboratorium Zoologi FMIPA, Universitas Pattimura Ambon pada Juni 2018 - Juni 2019.

\section{Bahan dan peralatan}

Bahan yang digunakan dalam penelitian ini adalah hewan model mencit $(M$. musculus L.), senyawa hasil sintesis analog kurkumin tidak simetris dengan metode konvensional (AKAS-k) dan metode microwave (AKAS-m), metanol, kunyit, etanol, $\mathrm{CCl}_{4}$, obat hati (Heap-Q), reagen kit GPT-ALAT (DSi), GOT-ALAT (DSi), formalin, $\mathrm{NaCl}$ fisiologi, aquades, buffer neutral formalin (BNF), pewarna hematoksilin-eosin,
Buffer fosfat, trichloroatic acid (TCA) 10\%, larutan 1.1.3.3-tetrametoxipropane (TMP), Tris- $\mathrm{HCl}, \mathrm{BHT} 5 \%$, NMPI (N-metil-2-fenilindol), $\mathrm{HCl}$ pekat, reduced $\mathrm{GSH}$, dTNB, dan reagen-kit DiaSys $\AA$. Peralatan yang digunakan dalam penelitian meliputi kandang, alat ukur kelembaban, termometer, pipa kapiler (Marienfed), tabung Eppendorf, sentrifus, micropestle, homogenizer, vortex, inkubator, timbangan hewan uji, micropipette (Socorex), jarum peroral, jarum suntik, holder mencit, alat-alat gelas, seperangkat alat bedah, Spetrofotometer FTIR dan LCMS.

\section{Pemeliharaan hewan model}

Hewan model mencit ( $M$. musculus $L$.) dipelihara menggunakan kandang dari polycarbonate serta mendapatkan pakan dan minum secara ad libitum. Mencit diaklimatisasi selama tujuh hari pada ruangan dengan siklus 12 jam (terang/gelap), kelembaban $70 \%$, suhu $22^{\circ} \mathrm{C}$. Pemberian sampel uji dilakukan secara oral.

\section{Preparasi sampel}

Sampel pada penelitian ini menggunakan produk hasil penelitian dari Kapelle et al. (2015a, 2015b). Produk hasil sintesis analog kurkumin (AKAS-k dan AKAS-m) memiliki perbedaan dari metode prosesnya. Produk AKAS-k merupakan produk yang diproses dengan menggunakan metode konvensional yakni proses pemanasan konvensional. Sedangkan untuk AKAS-m diproses menggunakan metode microwave. Kedua sampel dianalisis menggunakan LCMS dengan menggunakan pelarut metanol, dan untuk analisis gugus fungsi menggunakan FTIR. Sebagai kontrol pembanding menggunakan ekstrak kunyit yang diproses menggunakan metode maserasi dengan pelarut etanol. Untuk kontrol produk obat hati yang dipergunakan dipasaran yaitu Heap-Q.

\section{Prosedur in vivo}

Mencit galur Balb/c, berusia tiga minggu $(\mathrm{N}=80)$ dibagi menjadi 10 kelompok sesuai Tabel 1. Mencit diaklimatisasi selama 7 hari di ruangan dengan siklus 12 jam (terang/gelap), kelembaban $70 \pm 2 \%$, dan suhu $22 \pm 2^{\circ} \mathrm{C}$ dan dibagi menjadi kelompok perlakuan. Pada hari ke-7 (segera setelah periode aklimatisasi) mencit ditimbang dan $0,02 \mathrm{~mL} \mathrm{CCl} / 200 \mathrm{~g}$ berat badan dilarutkan 
Tabel 1. Pembagian kelompok dan perlakuan mencit

\begin{tabular}{cccl}
\hline Kelompok & Perlakuan & Dosis $(\mathrm{mg} / 200 \mathrm{~g}$ Berat Badan $)$ & \\
\hline A1 & AKAS-k & 13 & \\
A2 & AKAS-k & 26 & \\
A3 & AKAS-k & 52 & \\
B1 & AKAS-m & 13 & \\
B2 & AKAS-m & 26 & Kontrol positif \\
B3 & AKAS-m $-m$ & Kontrol positif \\
C+1 & Ekstrak kunyit & 52 & Kontrol negatif \\
C+2 & Obat Heap-Q & 130 & Kontrol normal \\
C-1 & CCl 4 & 60 & \\
N & Tanpa CCl4 & Tidak ada perlakuan & \\
\hline
\end{tabular}

Tabel 2. Hasil analisis spektrum FTIR

\begin{tabular}{lcc}
\hline \multirow{2}{*}{ Gugus fungsi } & \multicolumn{2}{c}{ Panjang Gelombang } \\
\cline { 2 - 3 } & Product AKAS-K & Product AKAS-M \\
\hline $\mathrm{C}=\mathrm{C}$ stretching aromatic & $1590 \mathrm{~cm}^{-1}$ dan $1490 \mathrm{~cm}^{-1}$ & $1591 \mathrm{~cm}^{-1}$ dan $1490 \mathrm{~cm}^{-1}$ \\
$\mathrm{C}=\mathrm{C}$ stretching aliphatic & $2923 \mathrm{~cm}^{-1}$ & $2924 \mathrm{~cm}^{-1}$ \\
$\mathrm{C}-\mathrm{O}-\mathrm{C}$ ether & $1027 \mathrm{~cm}^{-1}$ & $1027 \mathrm{~cm}^{-1}$ \\
$-\mathrm{CH}_{2}$ - bending methylene & $1450 \mathrm{~cm}^{-1}$ & $1450 \mathrm{~cm}^{-1}$ \\
Carbonyl & $1659 \mathrm{~cm}^{-1}$ & $1659 \mathrm{~cm}^{-1}$ \\
\hline
\end{tabular}

dalam minyak kelapa dan diberikan secara oral ke semua kelompok. Pada hari ke-14 perawatan diberikan kepada semua kelompok sesuai Tabel 1.

\section{Histopatologi}

Mencit percobaan dikorbankan pada hari ke-7, 14, 16, 20, dan 26, dengan cara dislokasi cervical. Mencit yang mati (dalam keadaan masih utuh) saat penelitian masih berlangsung akan dibedah untuk mengamati organ hati. Pengambilan gambar organ hati dilakukan ketika masih menempel pada tubuh mencit (setelah pembedahan). Parameter makroanatomi yang diamati adalah warna hati, kondisi hati, dan bentuk struktur hati. Organ hati difiksasi dengan larutan BNF. Sebelum proses pewarnaan, terlebih dahulu dilakukan proses deparafinisasi. Pewarnaan histopatologi hati dilakukan dengan metode pewarnaan hematoksilin-eosin (H\&E) (Kapelle et al. 2019).

\section{Pengukuran enzim darah}

Parameter biokimia darah yang diamati adalah analisis kadar enzim hati SGOT (serum glutamic oxaloacetic transaminase) yang juga memiliki nama lain alanine aminotransferase (ALT), dan SGPT (serum glutamic pyruvate transaminase) atau disebut aspartate aminotransferase (AST). Darah hewan coba diambil dan ditampung pada tabung Eppendorf, kemudian disentrifugasi (Hettich zentrifugen mikro 22R) pada kecepatan 10.000 rpm selama 10 menit pada suhu $4^{\circ} \mathrm{C}$ untuk mendapatkan serum darah. Pengukuran biokimia darah dilakukan menggunakan reagen-kit DiaSys ${ }^{\circledR}$ dan diukur dengan spektrofotometer UV-Vis (Genesis 10uv).

\section{HASIL DAN PEMBAHASAN}

Analisis LCMS sampel analog kurkumin asimetris yang diperoleh melalui metode konvensional dan microwave menghasilkan satu produk pada $\mathrm{tR}=3,27$ menit dengan berat molekul $278 \mathrm{~g} \mathrm{~mol}^{-1}$. Analisis lebih lanjut dari produk menggunakan spektrofotometer FTIR (Gambar 2) menunjukkan bahwa senyawa AKAS-k dan AKAS-m hampir identik (Lihat Tabel 2).

Bentuk sidik jari dari produk AKAS-k dan AKAS-m memiliki kesamaan serapan panjang gelombang sehingga disimpulkan senyawa tersebut identik. Dengan demikian, produk yang dihasilkan metode microwave dan metode konvensional adalah analog kurkumin dengan berat molekul $278 \mathrm{~g} \mathrm{~mol}^{-1}$ 
dan memiliki struktur kimia yang sama atau identik dengan analog kurkumin asimetris (Gambar 3). Pada pemanasan gelombang mikro, pelarut dan partikel larutan yang dipanaskan sehingga menimbulkan pemanasan yang merata (Tellez et al. 2011). Mekanisme pemanasan dari gelombang mikro adalah polarisasi dipolar, polarisasi interfacial, mekanisme konduksi (Lam dan Chase 2012).

Berdasarkan struktur kimia maka beberapa isomer dapat diperoleh sebagai produk yang akan tampak identik dengan FTIR atau LCMS tetapi memiliki aktivitas hepatoprotektif dengan potensi berbeda. Kapelle et al. (2015c) dalam studi aktivitas antikanker secara in vitro untuk sel kanker payudara T47D memperoleh hasil bahwa produk AKAS-m memberikan nilai $\mathrm{IC}_{50}$ yang lebih baik dari produk AKAS-k, AKS-m, AKS-k dengan nilai $7,247 \mu \mathrm{g} / \mathrm{mL}$. Produk isomer yang terbentuk dan paling stabil selama proses tersebut akan bertahan dan paling dominan. Jenis substituen, posisi dan orientasi dapat mempengaruhi stabilitas sistem (Tori 2015).

\section{Berat badan}

Efek pengobatan terhadap berat badan diukur pada hari ke-16, 20, dan 26 sebagai persentase berat badan dibandingkan dengan berat badan awal sebelum pengobatan (hari ke-14). Peningkatan berat badan terlihat pada semua kelompok, seperti yang diharapkan untuk mencit yang tumbuh dari remaja hingga dewasa. Namun, kenaikan berat badan berbeda secara signifikan antar kelompok (ANOVA $F(9,20)=4,485 ; p=$ 0,003). Hal ini menunjukkan bahwa pemberian analog kurkumin asimetris pada mencit dengan kerusakan hati yang diinduksi $\mathrm{CCl}_{4}$ meningkatkan kemampuan untuk menambah berat badan (Gambar 4). Persentase kenaikan berat badan untuk kontrol positif memberikan hasil yang lebih baik bila dibandingkan dengan produk AKAS. Pada hari ke-26, mencit mengalami

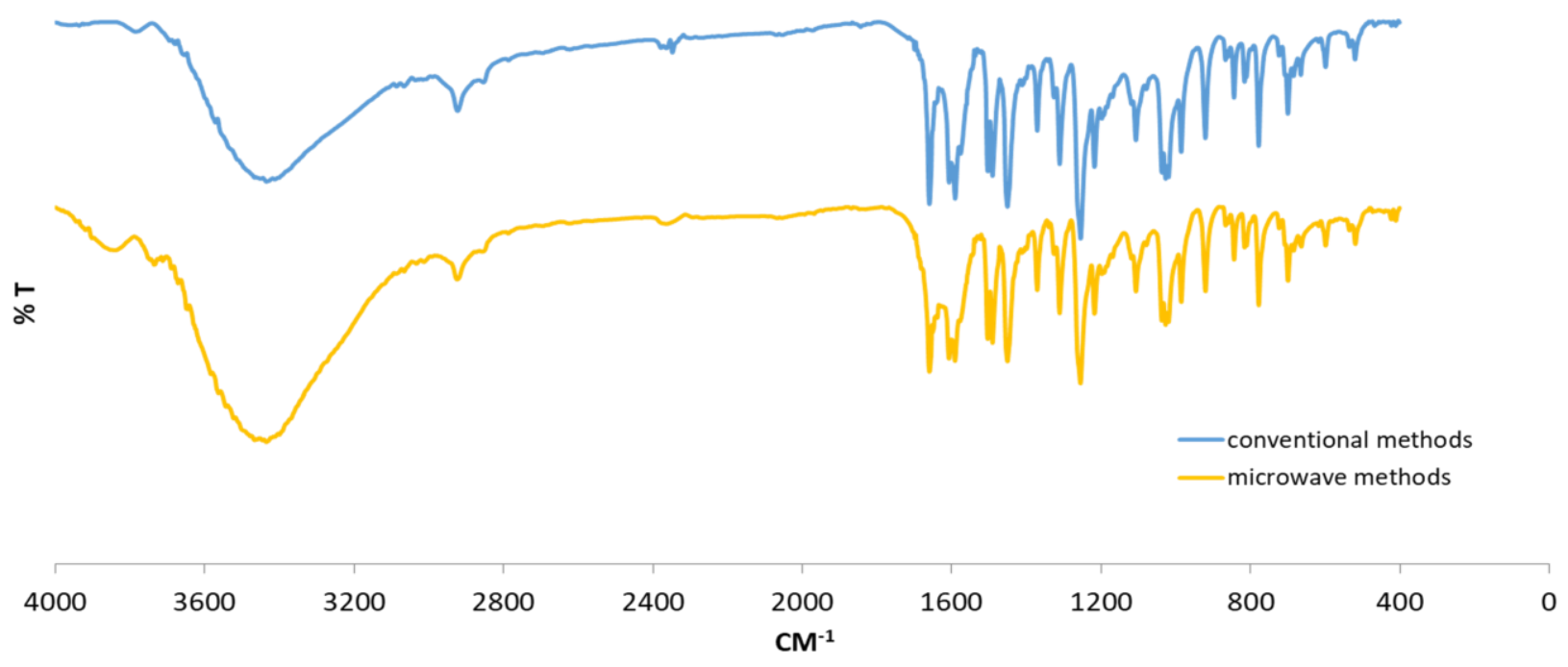

Gambar 2. Spektrum FTIR analog kurkumin asimetris<smiles>O=C(/C=C/C=C/c1ccc2c(c1)OCO2)c1ccccc1</smiles>

a
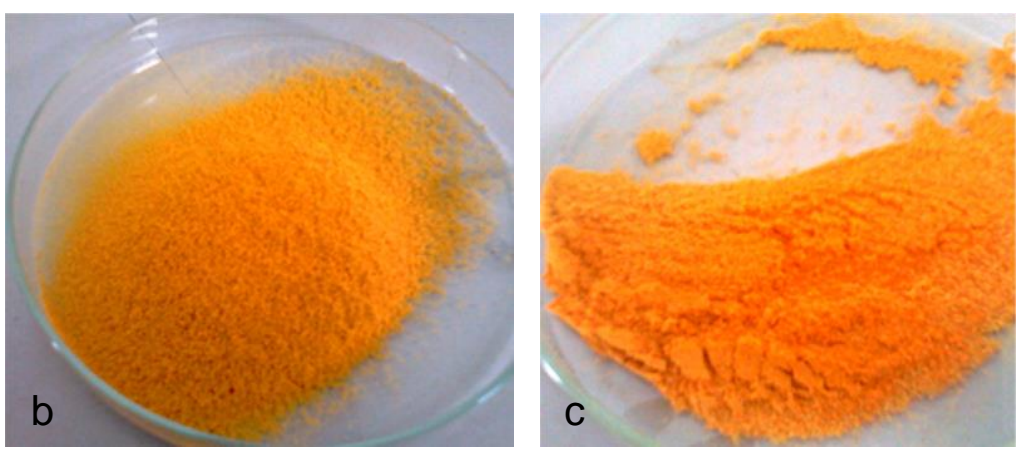

Gambar 3. a) Struktur kimia analog kurkumin asimtris, b) Sampel AKAS-k, c) Sampel AKAS-m 
perubahan berat badan terbesar untuk kontrol positif dan sama dengan kelompok normal. Analisis post hoc menunjukkan persamaan kontrol positif dengan kelompok lain, hanya ada perbedaan dengan kelompok C-1 dan B2 dengan nilai signifikan $(p=<0,05)$.

\section{Enzim hati}

Pemberian $\mathrm{CCl}_{4}$ dikaitkan dengan penurunan kadar ALT dan AST serum pada semua kelompok pada hari ke-16 dibandingkan dengan kelompok kontrol yang tidak diobati N. Pada kelompok kontrol negatif C-1 (diberikan $\mathrm{CCl}_{4}$ tetapi tidak diobati

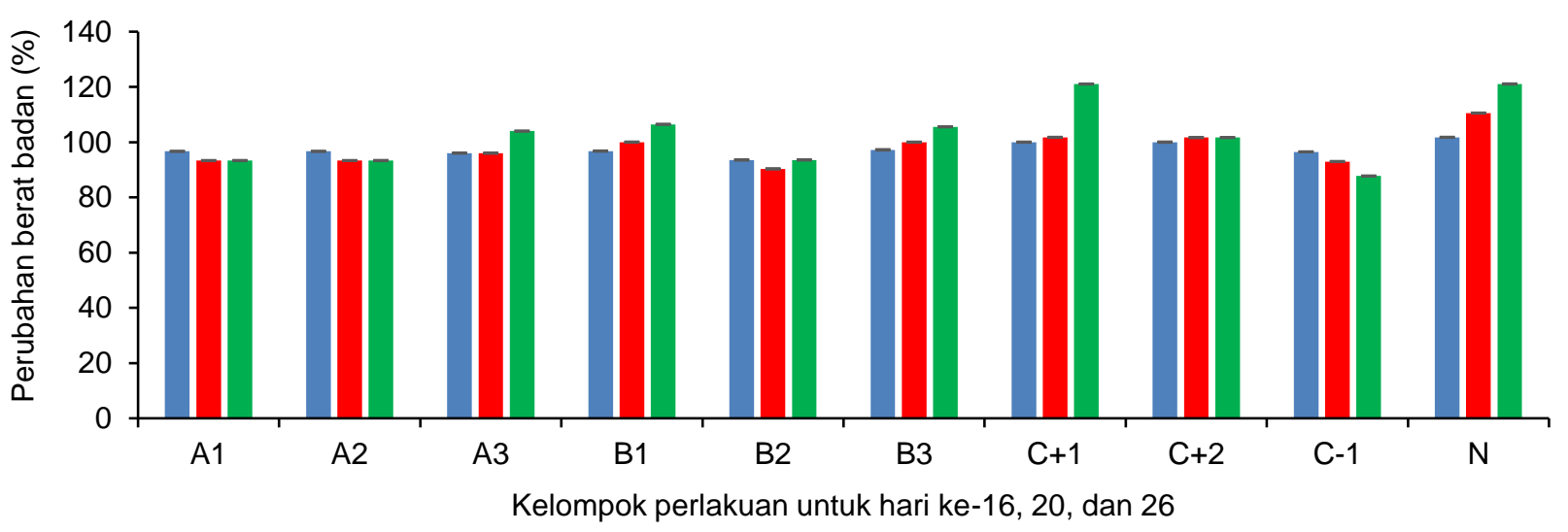

Gambar 4. Grafik persentase berat badan awal untuk setiap kelompok perlakuan pada hari ke-16 (biru), 20 (merah), dan 26 (hijau)

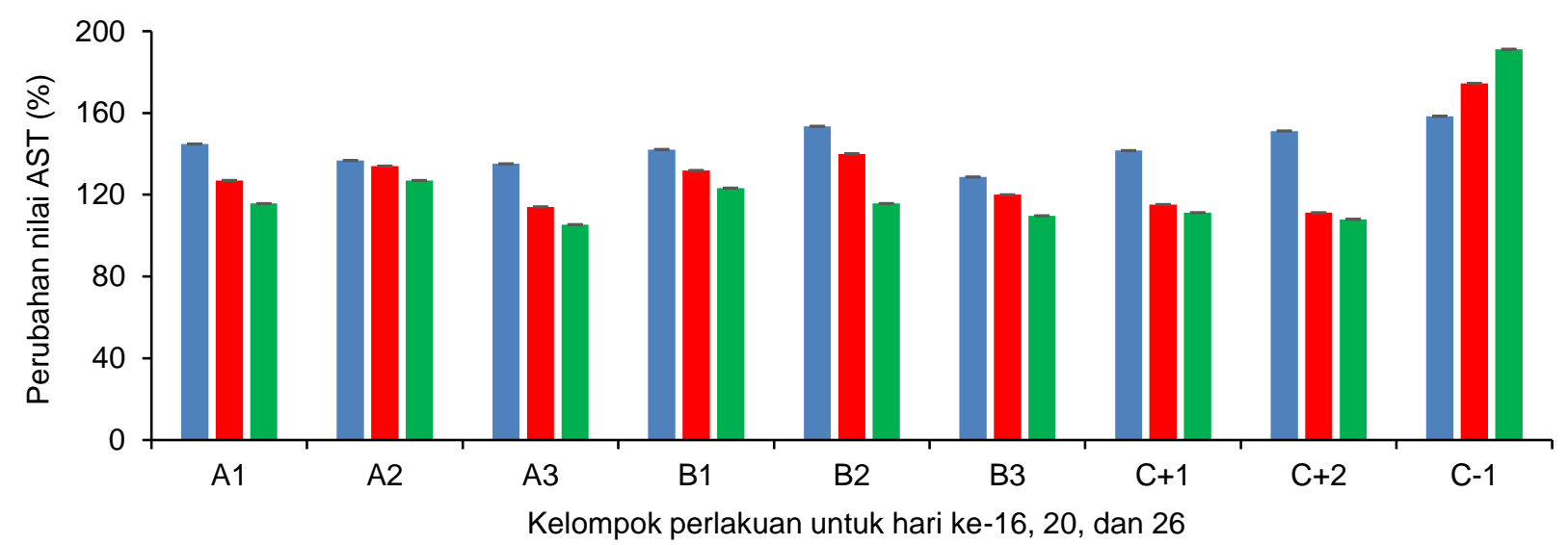

Gambar 5. Grafis persentase perubahan nilai AST untuk setiap kelompok perlakuan yang diukur pada hari ke-16 (biru), 20 (merah), dan 26 (hijau)

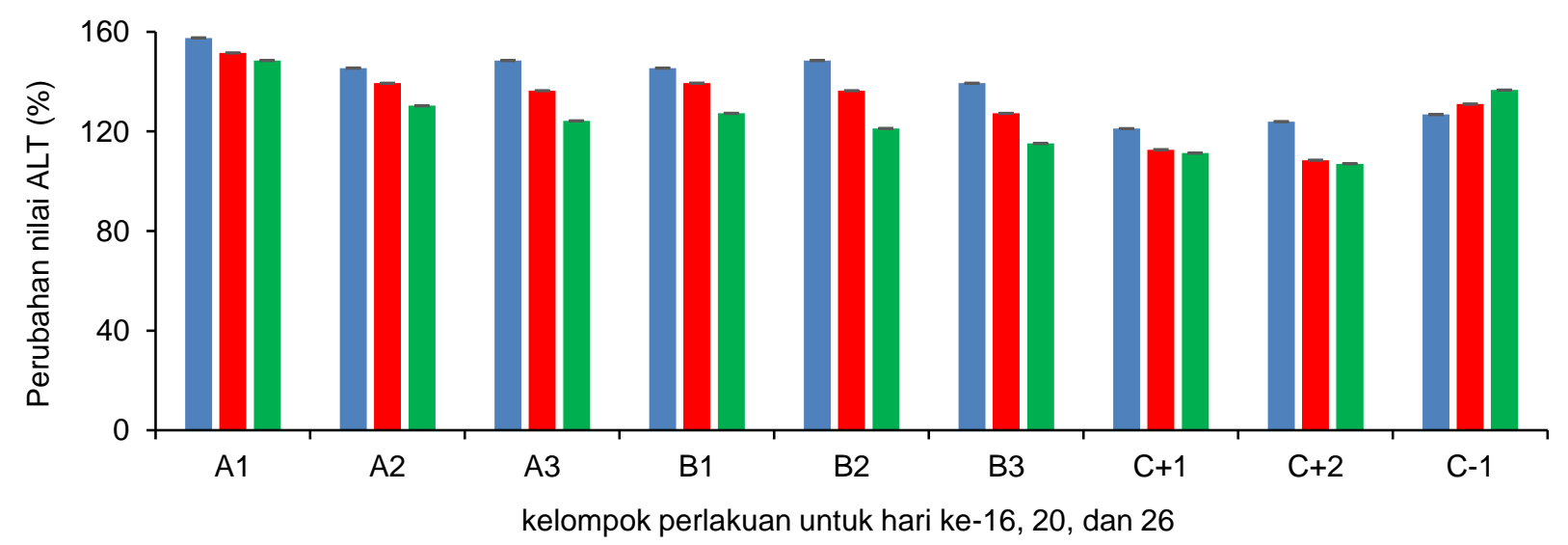

Gambar 6. Grafis persentase perubahan nilai ALT untuk setiap kelompok perlakuan yang diukur pada hari ke-16 (biru), 20 (merah), dan 26 (hijau) 
dengan senyawa apa pun), nilai ALT dan AST tetap tinggi hingga hari ke-26. Pada semua kelompok mencit yang diberi perlakuan, nilai AST menurun secara signifikan dari hari ke16 hingga 20 dan 26, menunjukkan peningkatan fungsi hati $(F(8,18)=6,123 ; p=$ 0,001 ) (Gambar 5). Di antara mencit yang diobati dengan analog kurkumin asimetris, kadar AST terendah diamati pada kelompok A3 (dosis AKAS-k 52 mg/200 g berat badan) dan setara dengan yang ada pada kelompok kontrol positif $\mathrm{C}+1$ (ekstrak kunyit $130 \mathrm{mg} / 200$ $g$ berat badan) $(p=1.000)$ dan kelompok kontrol $\mathrm{C}+2$ (Heap-Q obat $60 \mathrm{mg} / 200 \mathrm{~g}$ berat badan) $(p=1.000)$.

Perubahan ALT umumnya kurang dramatis dibandingkan dengan AST. Tingkat ALT menurun pada semua kelompok mencit yang diberi perlakuan pada hari ke-16, 20, dan 26 (Gambar 6) dan perbedaan yang signifikan diamati dalam efikasi $(F(8,18)=$ $12,809, p=0,001)$. Kelompok perlakuan B3 (dosis AKAS-m $52 \mathrm{mg} / 200 \mathrm{~g}$ berat badan) memiliki nilai ALT yang lebih rendah dibandingkan dengan kelompok lain (asimetrik kurkumin analog). Kontrol positif $(\mathrm{C}+1$ dan $\mathrm{C}+2)$ memiliki nilai $\mathrm{ALT}$ yang lebih rendah dibandingkan dengan perawatan produk analog asimetris kurkumin.

\section{Morfologi hati}

Pemberian $\mathrm{CCl}_{4}$ menyebabkan perubahan morfologis progresif yang diharapkan pada hepatosit mencit yang tidak diobati (Gambar 7). Hepatosit normal memiliki susunan lobular yang teratur dengan vena sentral yang seragam dan kosong. $\mathrm{CCl}_{4}$ menginduksi perubahan sitoplasmik vacuolar dan microvacuolar pada hepatosit. Dalam beberapa kasus, lemak terlihat di daerah vena sentral, dan hepatosit yang membengkak menyebabkan penyempitan sinusoid (Gambar 7). Sebaliknya, gambar mikroskopis dari hati mencit yang diberikan

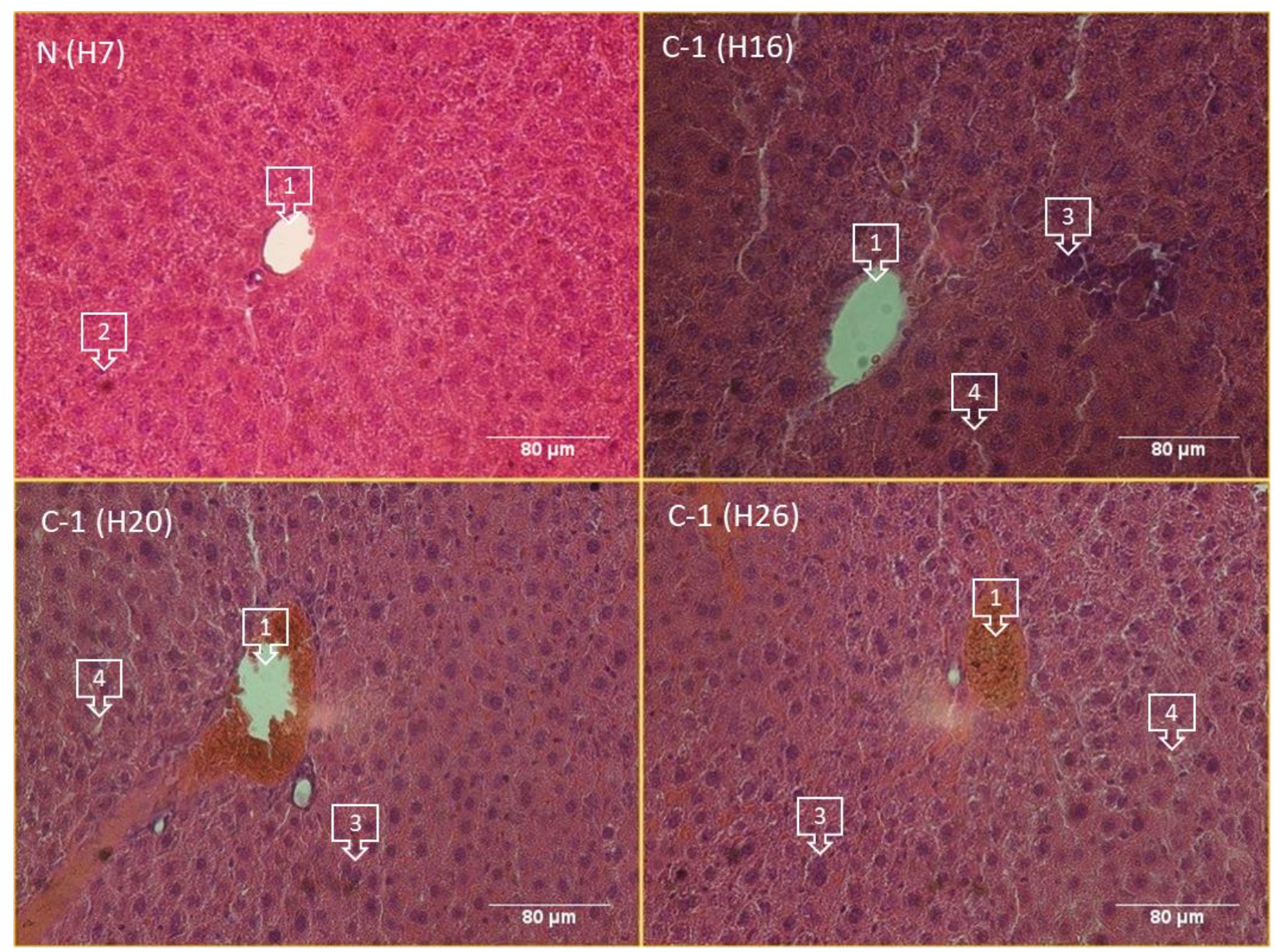

1. Central vein; 2. Normal hepatocytes; 3 . Hepatocytes; 4. Sinusoid

Gambar 7. Gambar mikroskopis dari struktur hati normal mencit kontrol (N) dan hati pada mencit dengan kerusakan yang disebabkan oleh CCl4 (C-1). Metode H\&E, Pembesaran 400× 


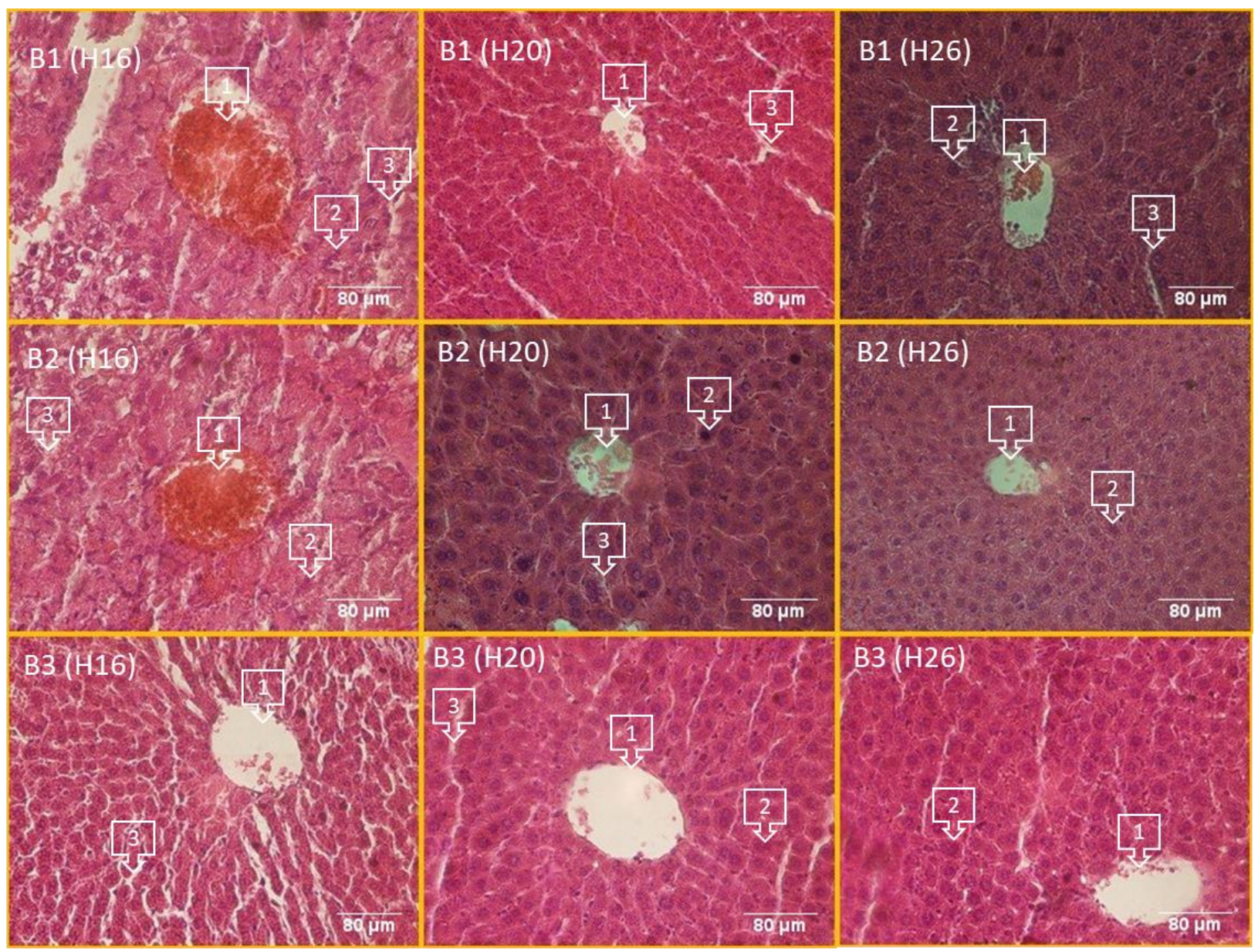

\section{Central vein; 2. Hepatocytes; 3. Sinusoid}

Gambar 9. Gambar mikroskopis struktur hati mencit selama tiga dosis pengobatan AKAS-m. Metode H\&E, Pembesaran 400x

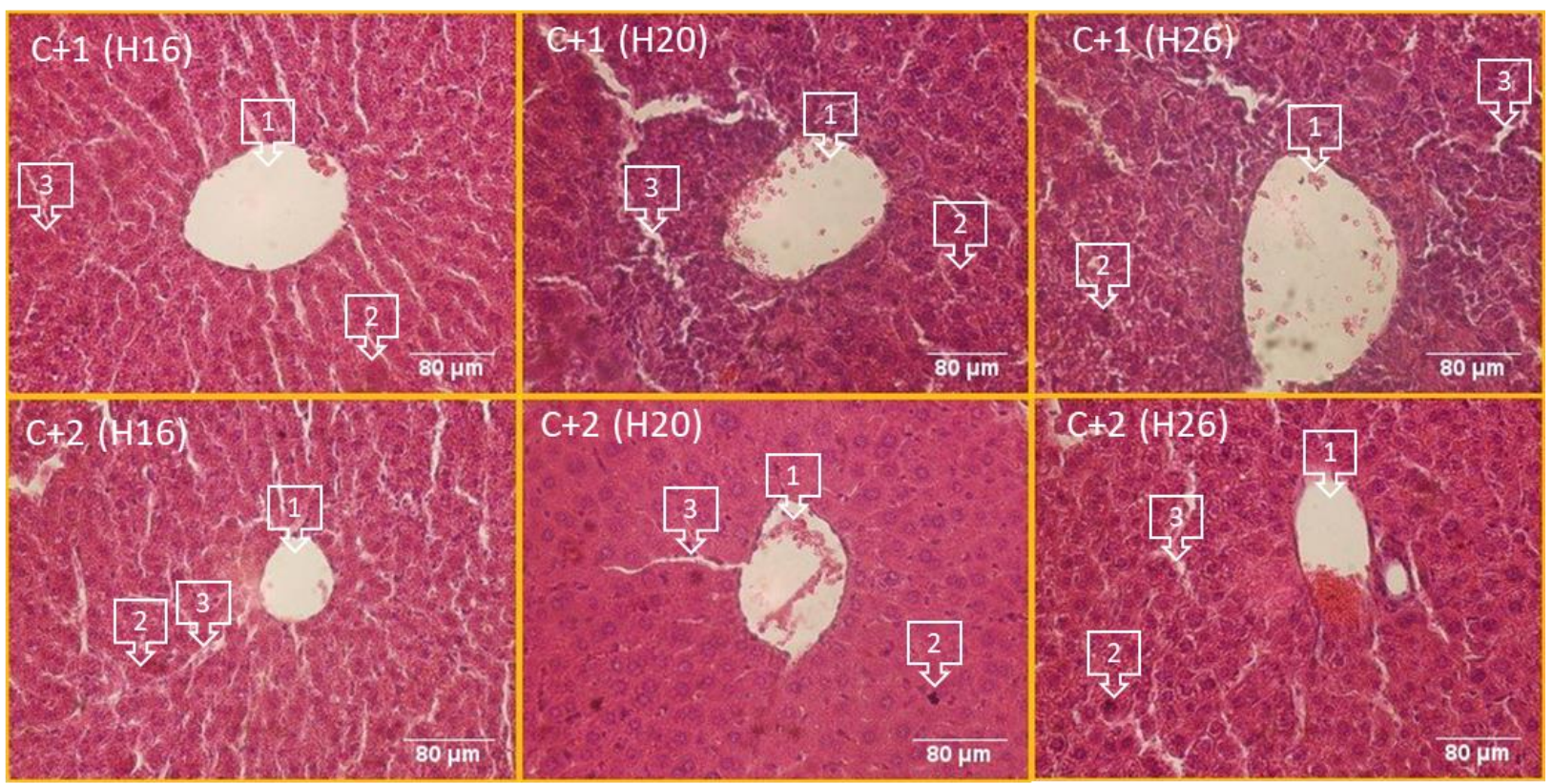

\section{Central vein; 2. Hepatocytes; 3. Sinusoid}

Gambar 10. Gambar mikroskopis struktur hati mencit untuk kontrol positif (Heap-Q atau kunyit). Metode H\&E, Pembesaran 400x 
berbagai perawatan ditunjukkan pada Gambar 8, 9, dan 10.

Hati kontrol positif mencit yang diobati dengan ekstrak kunyit di Grup C+1 (ekstrak kunyit $130 \mathrm{mg} / 200 \mathrm{~g}$ berat badan) memiliki puing-puing di vena sentral dan jaringan lemak di hepatosit meskipun menggunakan dosis yang lebih tinggi daripada yang dibutuhkan untuk AKS. Namun, resolusi perubahan hati mikroskopis terbukti pada hari ke-26 (lihat Gambar 10). Efek morfologis produk analog asimetris kurkumin sintetik paling jelas pada mencit kelompok A3 (AKAS-k dosis $52 \mathrm{mg} / 200 \mathrm{~g}$ berat badan) pada hari ke-26, dimana vena sentral mulai terlihat bersih dan tidak ada tanda degenerasi hepatoseluler atau nekrosis (Gambar 8 dan 9). Peningkatan berkelanjutan terlihat antara mencit yang dihentikan pada hari ke-20 dan 26. Dengan demikian, analog kurkurmin asimetris berpotensi menjadi hepatoprotektor karena mereka mampu mengurangi mikroskopis sel hati pada dosis yang lebih rendah daripada yang diperlukan untuk efek kunyit.

Kedua produk analog kurkumin asimetris dalam waktu pengobatan yang lebih lama terlihat vena sentral bersih dan tidak adanya hepatosit lemak, menunjukkan perbaikan kerusakan sel. Perbedaan histologis untuk kedua analog terkait dengan tingkat dosis. Pada produk B (AKAS-m), semakin besar dosisnya, kerusakan sel masih ada, sinusoid masih terlihat lebar. Berbeda dengan A (AKAS-k) yang memiliki dosis lebih besar, vena sentral yang terlihat lebih bersih dan lemak telah berkurang. Efektivitas analog kurkumin asimetris sintetik dalam perlindungan hati dapat dikaitkan dengan kelompok aktif dalam senyawa. Analog kurkumin asimetris memiliki gugus alkena, benzena, karbonil dan eter yang bermuatan negatif, sehingga memungkinkan untuk menangkap radikal bebas dan mengubahnya menjadi molekul netral (Gambar 3). Jika radikal bebas ditangkap, maka kerusakan sel lebih lanjut dapat dihindari dan proses penyembuhan alami dapat terjadi. Dalam penelitian ini, perbaikan sel hati setelah pengobatan analog kurkumin terlihat. Penelitian ini sejalan dengan penelitian yang dilakukan oleh Kapelle et al (2019) bahwa produk analog kurkumin yang diproses dengan metode konvensional lebih hepatoprotektif.

\section{KESIMPULAN}

Metode proses sintesis memiliki efek pada kemampuan hepatoprotektif produk analog asimetris kurkumin yang dihasilkan dari minyak lawang dalam model kerusakan hati mencit $\mathrm{CCl}_{4}$. Pemberian AKAS-k dengan dosis $52 \mathrm{mg} / 200 \mathrm{~g}$ berat badan dari hari ke14 hingga 26 setelah induksi kerusakan hati oleh $\mathrm{CCl}_{4}$ menghasilkan peningkatan berat badan yang meningkat, tingkat AST dan ALT yang lebih rendah, dan tampilan mikroskopis sel hati sama dan bahkan lebih baik dari kunyit dan Heap-Q. Produk analog asimetris kurkumin yang diproses dengan metode pemanasan konvensional lebih hepatoprotektif pada dosis yang lebih tinggi daripada produk yang diproses dengan metode microwave, disebabkan karena perbedaan dalam geometri senyawa.

\section{UCAPAN TERIMA KASIH}

Ucapan terima kasih ditujukan kepada Direktorat Riset dan Pengembangan Masyarakat, Direktorat Jendral Penguatan Riset dan Pengembangan, Kementerian Riset, Teknologi dan Pendidikan Tinggi, Sesuai Dengan Kontrak Penelitian Pasca Doktor dengan Nomor: 081/SP2H/LT/DRPM/2018.

\section{DAFTAR PUSTAKA}

Aggarwal BB, Barton D, Wu SB (2010) Curcumin. Oncology Nurse Edition Vol 24 Issue 4. Cancer Network. https://www.cancernetwork.com/view/c urcumin. Accessed on 26 January 2020

Anand $P$, Thomas SG, Kunnumakkara $A B$, Sundaram C, Harikumar KB, Sung B, Tharakan ST, Misra K, Priyadarsini IK, Rajasekharan KN, Aggarwal BB (2008) Biological activities of curcumin and its analogues (congeners) made by man and mother nature. Biochem Pharmacol 76: 1590-1611. doi: 10.1016/j.bcp.2008.08.008

Dandawate PR, Vyas A, Ahmad A, Banerjee S, Deshpande J, Swamy KV, Jamadar A, Dumhe-Klaire AC, Padhye S, Sarkar FH (2012) Inclusion complex of novel curcumin analogue CDF and $\beta$ cyclodextrin (1:2) and its enhanced in vivo anticancer activity against 
pancreatic cancer. Pharm Res 29: 1775-1786. doi: 10.1007/s11095-0120700-1

Irving GRB, Karmokar A, Berry DP, Brown K, Steward WP (2011) Curcumin: The potential for efficacy in gastrointestinal diseases. Best Pract Res Clin Gastroenterol 25: 519-534. doi: 10.1016/j.bpg.2011.09.005

Jin $X$, Zhang $Z H$, Sun E, Tan XB, Li SL, Cheng XD, You M, Jia XB (2013) Enhanced oral absorption of 20(S)protopanaxadiol by self-assembled liquid crystalline nanoparticles containing piperine: in vitro and in vivo studies. Int J Nanomed 8: 641-652. doi: 10.2147/IJN.S38203

Johnson JJ, Mukhtar H (2007) Curcumin for chemoprevention of colon cancer. Cancer Lett 255: 170-181. doi: 10.1016/j.canlet.2007.03.005

Kapelle IBD, Irawadi TT, Rusli MS, Mangunwidjaja D, Mas'ud ZA (2016) Rekayasa proses sintesis piperonal kulit lawang (Cinnamomum culilawan Blume) sebagai prekursor obat kanker. J Penelit Hasil Hutan 34: 217-229. doi: 10.20886/jphh.2016.34.3.217-229

Kapelle IBD, Irawadi TT, Rusli MS, Mangunwidjaja D, Mas'ud ZA (2015a) Synthesis of new curcumin analogues from kulit lawang oils using the conventional method and microwave. Sci J Chem 3: 50-56. doi: 10.11648/j.sjc.20150303.13

Kapelle IBD, Irawadi TT, Rusli MS, Mangunwidjaja D, Mas'ud ZA (2015b) Synthesis of asymmetric curcumin analogues from cullilawan oil using conventional and microwave method. Procedia Chem 16: 480-488. doi: 10.1016/j.proche.2015.12.082

Kapelle IBD, Irawadi TT, Rusli MS, Mangunwidjaja D, Mas'ud ZA (2015c) The influence of synthesis methods against anti-cancer activity of curcumin analogous. Cancer Res J 3: 68-75. doi: 10.11648/j.crj.20150304.12

Kapelle IBD, Manalu W, Mainassy MC (2019) Influence of process methods on the hepatoprotective effect of curcumin analogs synthesized from culilawan oil in mice (Mus musculus L.) with $\mathrm{CCl}_{4}$ induced liver damage. Ohio J Sci 119: 28-37. doi: 10.18061/ojs.v119i2.6652
Khan RA, Khan MR, Ahmed M, Sahreen S, Shah NA, Shah MS, Bokhari J, Rashid U, Ahmad B, Jan S (2012) Hepatoprotection with a chloroform extract of Launaea procumbens against $\mathrm{CCl}_{4}$-induced injuries in rats. BMC Complement Altern Med 12: 114. doi: 10.1186/1472-6882-12-114

Lam SS, Chase HA (2012) A review on waste to energy processes using microwave pyrolysis. Energies 5: 4209-4232. doi: 10.3390/en5104209

Mehta A, Kaur G, Chintamaneni M (2012) Piperine and quercetin enhances antioxidant and hepatoprotective effect of curcumin in paracetamol induced oxidative stress. Int J Pharm 8: 101107. doi: 10.3923/ijp.2012.101.107

Moorthi C, Kathiresan K (2013) Curcuminpiperine/curcumin-quercetin/curcumin -silibinin dual drug-loaded nanoparticulate combination therapy: $A$ novel approach to target and treat multidrug-resistant cancers. J Med Hypoth Ide 7: 15-20. doi: 10.1016/j.jmhi.2012.10.005

Qian Y, Zhong P, Liang D, Xu Z, Skibba M, Zeng C, Li X, Eie T, Wu L, Liang G (2015) A newly designed curcumin analog Y20 mitigates cardiac injury via anti-inflammatory and anti-oxidant actions in obese rats. PLoS One 10: e0120215.

doi: 10.1371/journal.pone.0120215

Shang $Y J$, Jin $X L$, Shang $X L$, Tang JJ, Liu GY, Dai F, Qian YP, Fan GJ, Liu Q, Zhou B (2010) Antioxidant capacity of curcumin-directed analogues: Structure-activity relationship and influence of microenvironment. Food Chem 119: 1435-1442. doi: 10.1016/j.foodchem.2009.09.024

Tellez HM, Alquisira JP, Alonso CR, Cortes JGL, Toledano CA (2011) Comparative kinetic study and microwaves nonthermal effects on the formation of poly(amic acid) 4,4'(hexafluoroisopropylidene)diphthalic anhydride (6FDA) and 4,4'(hexafluoroisopropylidene) bis ( $p$ phenyleneoxy) dianiline (BAPHF). Reaction activated by microwave, ultrasound and conventional heating. Int J Mol Sci 12: 6703-6721. doi: $10.3390 / \mathrm{ijms} 12106703$ 
Thomas SL, Zhao J, Li Z, Lou B, Du Y, Purcell J, Snyder JP, Khuri FR, Liotta D, Fu H (2010) Activation of the p38- pathway by a novel monoketone curcumin analog, EF24, suggests a potential combination strategy. Biochem Pharmacol 80: 1309-1316. doi: 10.1016/j.bcp.2010.06.048

Tori M (2015) Relative stability of cis- and transhydrindanones. Molecules 20: 15091518. doi: 10.3390/molecules20011509

Villegas AM, Catalan LE, Venegas IM, Garcia JV, Altamirano HC (2011) New catechol derivatives of safrole and their antiproliferative activity towards breast cancer cells. Molecules 16: 4632-4641. doi: 10.3390/molecules 16064632

Yang CH, Yue J, Sims M, Pfeffer LM (2013) The curcumin analog EF24 targets NF$\mathrm{kB}$ and miRNA-21, and has potent anticancer activity in vitro and in vivo.
PLoS One 8: e71130. doi: 10.1371/journal.pone.0071130

Ye MX, Li Y, Yin H, Zhang J (2012) Curcumin: updated molecular mechanisms and intervention targets in human lung cancer. Int J Mol Sci 13: 3959-3978. doi: 10.3390/ijms13033959

Zhang Q, Zhong Y, Yan LN, Sun X, Gong T, Zhang ZR (2011) Synthesis and preliminary evaluation of curcumin analogues as cytotoxic agents. Bioorg Med Chem Lett 21: 1010-1014. doi: 10.1016/j.bmcl.2010.12.020

Zhao C, Yang J, Wang Y, Liang D, Yang X, Li X, Wu J, Wu X, Yang S, Li X, Liang G (2010) Synthesis of mono-carbonyl analogues of curcumin and their effects on inhibition of cytokine release in LPSstimulated RAW 264.7 macrophages. Bioorg Med Chem 18: 2388-2393. doi: 10.1016/j.bmc.2010.03.001 